\title{
Variability for Leaf and Seed Glucosinolate Contents and Profiles in a Germplasm Collection of the Brassica juncea
}

Shilpa Gupta ${ }^{1 *}$, Manjeet K Sangha ${ }^{1}$, Gurpreet Kaur ${ }^{2}$, Amarjeet K Atwal ${ }^{2}$, Shashi Banga ${ }^{2}$ and Surinder S. Banga ${ }^{2}$

${ }^{1}$ Department of Biochemistry, Punjab Agricultural University, Ludhiana, Punjab- 141004, India

${ }^{2}$ Department of Plant Breeding and Genetics, Punjab Agricultural University, Ludhiana, Punjab- 141004, India

\begin{abstract}
Aim: A renewed interest in glucosinolates (GSLs) as compounds with biocidal and anticarcinogenic activity demands evaluation of the available variability in germplasm collections. The objective of the present study was to evaluate a germplasm collection of the Brassica juncea for total content and profile of leaf and seed GSLs.

Methods: A total of 366 entries of a RIL population derived from cross of NUDH-YJ-04 and RL-1359, were nondestructively analyzed by near-infrared reflectance spectroscopy by means of previously developed calibration equations. Out of 366 lines, 97 lines were selected on the basis of glucosinolate range and further analyzed by ultra performance liquid chromatography for total GSL content and the concentrations of individual components i.e. sinigrin, glucoiberin, epiprogoitrin, gluconapin, gluconasturtiin and gluconeobrassicin.

Results and conclusion: The collection contained great variability for GSL content and profile. Remarkable variation in glucosinolate content and profiles from different tissues within one plant may reflect different contro mechanism operating on the glucosinolate biosynthetic pathway in different tissues. In the present study no correlation has been observed in leaf and seed glucosinolates. NIRS screening followed by further HPLC analyses on preselected entries led to a fast and comprehensive evaluation of variability for total content and profile of seed GSLs, which represents an important advance in the evaluation of GSLs in Brassica germplasm.
\end{abstract}

Keywords: Brassica juncea; Glucosinolate; Recombinant inbred lines; NIRS; UPLC

\section{Introduction}

Modern cultivars and breeding lines of Indian mustard (Brassica juncea (L.) Czern.+ Coss.) yield high-quality oil, high-protein seed meal, and are relatively resistant to heat stress, water stress, podshattering and fungal diseases [1], and could be used as an oilseed crop in the Mediterranean area [2]. Glucosinolates (GSLs) are a family of secondary plant metabolites particularly abundant in seeds and green tissues of the family Brassicaceae. They consist of a glycone moiety and a variable aglycone side chain, which derives from the amino acid pathway. More than 140 different GSLs, showing different side chain structure, have been identified in the plant kingdom, mainly in the Brassicaceae [3-5]. Both the GSLs and their degradation products are associated with antinutritive and toxic effects, limiting the usefulness of seeds and seed meals for human and animal feed [6]. Because of their detrimental effects, plant breeding has been focused on a drastic reduction of seed GSL content in the major oil crops of the family, i.e. Brassica napus, B. rapa, and B. juncea [7] with a view to using the defatted meal for animal feeds on a large scale. On the other hand, GSLs and their hydrolysis products possess beneficial properties as well. They show broad biocidal activity which can be used as an alternative to synthetic pesticides for pest and disease control $[8,9]$. Furthermore, GSLs exert a positive influence against biological processes associated with cellular damage and cancer development [10-12]. The biological activity of the GSLs is determined by both the GSL concentration and composition $[8,9]$. Therefore, the identification of sources of variability for individual GSLs is important for the development of cultivars with increased levels of specific GSLs. Large-scale germplasm evaluation for GSL profiles with traditional chromatographic methods is expensive, time consuming, and requires the destruction of valuable germplasm materials. Alternatively, total GSL content and the concentration of several individual GSLs can be nondestructively analysed by near infrared reflectance spectroscopy (NIRS) [13]. NIRS analyses are faster but also less accurate than the standard method of High Performance Liquid Chromatography (HPLC) [14,15]. However, previous studies on evaluation of Brassica germplasm for seed quality traits revealed that a combination of NIRS screening followed by analysis of the preselected accessions by a reference method leads to an efficient identification of variants with a simultaneous minimization of time, costs, and destruction of material [16]. The objective of the present study was to evaluate a germplasm collection of the genus Brassica for total seed and leaf GSL content and profile.

\section{Materials and Methods}

The original germplasm collection included a RIL population comprising 366 entries from cross of European juncea NUDH-YJ-04 and Indian juncea RL-1359, which were analysed for GSL content and composition by NIRS (Near infrared reflectance spectrometry) and UPLC (ultra performance liquid chromatography). The nomenclature used and the delimitation of the species is based on Gladis [17] The germplasm accessions were collected from Oilseeds section, department of plant Breeding and Genetics, Punjab agricultural University, Ludhiana, Punjab.

Near-infrared reflectance spectroscopy and HPLC analyses were performed as described by Font et al. [18]. Intact-seed samples of

${ }^{*}$ Corresponding author: Shilpa Gupta, Department of Biochemistry, Punjab agricultural University, Ludhiana, Punjab-141004, India, E-mail: shilpagupta09@gmail.com

Received March 22, 2012; Accepted October 19, 2012; Published October 23, 2012

Citation: Gupta S, Sangha MK, Kaur G, Atwal AK, Banga S, et al. (2012 Variability for Leaf and Seed Glucosinolate Contents and Profiles in a Germplasm Collection of the Brassica juncea. Biochem Anal Biochem 1:120. doi:10.4172/2161 1009.1000120

Copyright: (C) 2012 Gupta S, et al. This is an open-access article distributed under the terms of the Creative Commons Attribution License, which permits unrestricted use, distribution, and reproduction in any medium, provided the original author and source are credited. 
the 366 entries were scanned by NIRS. Calibration equations for total GSL content were used for estimation (see systematic names of glucosinolates in table 1). A selection based on NIRS estimations was performed and 97 selected samples were further analyzed by UPLC. The selection was made to include entries which covered the complete range of glucosinolates in RIL population i.e. entries with very high, high, intermediate, low and very low concentration of GSL.

Seed and leaf glucosinolates profiles were estimated by ultra performance liquid chromatography (UPLC) (Waters UPLC) following the method of Sorenson et al. [19]. Solvents used were acetonitrile and water. The gradient used for separation is mentioned in table 2

The percentages of aliphatic, aromatic and aryl glucosinolates were calculated following the software "Empower".

Conc. of individual glucosinolate component $=\frac{\text { Conc. of internalstd }}{\text { Area of internalstd }} \times$

Area of unknown $\times$ Responce factor for each glucosinolate component

\section{Results and Discussion}

Initially, total seed glucosinolate content has been estimated in 366 lines via NIRS. Out of these 366, 97 RILs were selected on the basis of glucosinolate range observed in whole RIL population. These 97 lines were distributed in seven categories covering complete range (Table 3 ). Seed and leaves of these 97 lines were further screened for total GSL content and composition via NIRS and UPLC (Table 4 and 5).

\section{Variation for total seed glucosinolate content in seeds}

Glucosinolates are antinutritional components and the international standards for canola varieties require glucosinolate level to be $<30 \mu \mathrm{mol} / \mathrm{g}$ seed. With NIRS, in selected accessions, total GSL ranged from 28.85 to $115.88 \mu \mathrm{mol} / \mathrm{g}$ tissue, with mean value of 69.39 \pm 0.26 . The frequency distribution of glucosinolates in these 97 lines also showed a near normal distribution (Figure 1). In this case also,

\begin{tabular}{|l|l|l|}
\hline Systematic name & Trivial name & Abbreviation \\
\hline 2-Propenyl & Sinigrin & SIN \\
\hline 3-Methylsulphinylpropyl & Glucoiberin & IBE \\
\hline 3-Butenyl & Gluconapin & GNA \\
\hline (2S)2-Hydroxy-3-butenyl & Epiprogoitrin & EPI \\
\hline N-Methoxy-3-indolmethyl & Neoglucobrassicin & NEO \\
\hline 2-Phenylethyl & Gluconasturtiin & NAS \\
\hline
\end{tabular}

Table 1: systematic names of glucosinolates.

\begin{tabular}{|l|l|l|l|}
\hline Time (min) & Acetonitrile (\%) & Water (\%) & Flow rate $(\mathbf{m l} / \mathbf{m i n}$.) \\
\hline $0-3.64$ & 1 & 99 & 0.4 \\
\hline $3.64-4.04$ & 19 & 81 & 0.4 \\
\hline $4.04-4.93$ & 1 & 99 & 0.4 \\
\hline $4.93-5.00$ & 1 & 99 & 0.4 \\
\hline
\end{tabular}

Table 2: gradient used for separation in UPLC (Ultra Performance Liquid Chromatography).

\begin{tabular}{|l|l|}
\hline Range & No. of genotypes \\
\hline $0-20$ & 0 \\
\hline $21-40$ & 8 \\
\hline $41-60$ & 21 \\
\hline $61-80$ & 46 \\
\hline $81-100$ & 15 \\
\hline $101-120$ & 7 \\
\hline
\end{tabular}

Table 3: Selected 97 individuals in different ranges of glucsoinolate content in seeds ( $\mu$ mole/g seed) of RIL population.

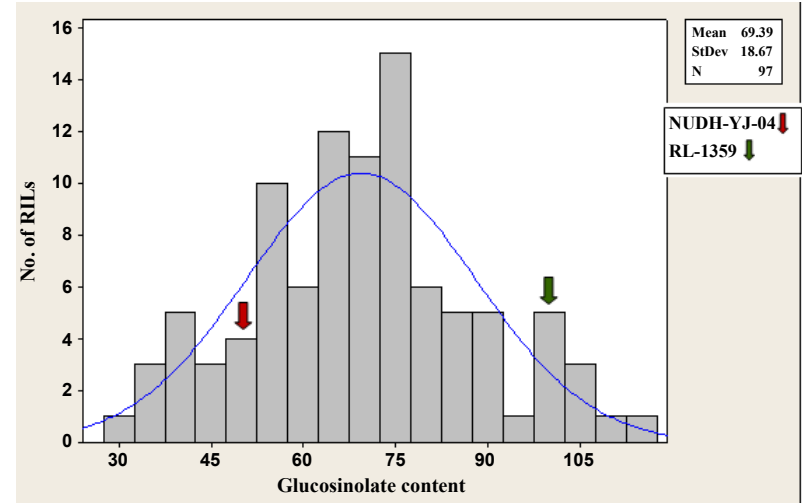

Figure 1: Frequency distribution of Glucosinolates in seeds via NIRS

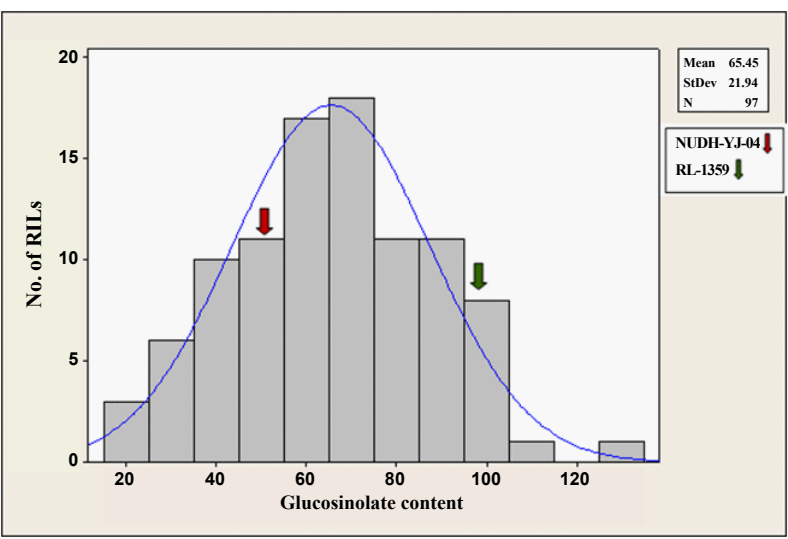

Figure 2: Frequency distribution of Glucosinolates in seeds via UPLC.

most of the inbred lines were in the range of 41 to $60 \mu \mathrm{mol} / \mathrm{g}$ seed glucosinolate content (21), 46 had occurred in a range of $61-80 \mu \mathrm{mol} / \mathrm{g}$ seed and 15 had in range of 81-100 $\mu \mathrm{mol} / \mathrm{g}$ seed while range of 21-40 and 101-120 showed lesser number of lines i.e. 8 and 7 respectively and it was found that there was no line in $0-20 \mu \mathrm{mol} / \mathrm{g}$ seed. With UPLC, a little bit variation has been observed as compared to NIRS. The selected 97 lines harboured the range of 15.73-127.61 $\mu \mathrm{mol} / \mathrm{g}$ DW seed with mean value of $65.45 \pm 0.33$. RL-1359 and NUDH-YJ-04 showed glucosinolate content of 97.51 and $52.54 \mu \mathrm{mol} / \mathrm{g}$ DW seed respectively. The frequency distribution of glucosinolates again showed a normal distribution (Figure 2), indicating a quantitative inheritance. Most of the recombinant inbred lines fell in the range of 41 to $60 \mu \mathrm{mol} / \mathrm{g}$ DW seed glucosinolate content (32), $30 \mathrm{had}$ in range of $61-80 \mu \mathrm{mol} / \mathrm{g} \mathrm{DW}$ seed and $17 \mathrm{had}$ in range of $81-100 \mu \mathrm{mol} / \mathrm{g}$ DW seed. $21-40 \mu \mathrm{mol} / \mathrm{g} \mathrm{DW}$ seed had 11 lines and 101-120 $\mu \mathrm{mol} / \mathrm{g}$ DW seed had 5 lines whereas only a single line was there in $0-20 \mu \mathrm{mol} / \mathrm{g}$ DW seed range and 121$140 \mu \mathrm{mol} / \mathrm{g}$ DW seed range (Table 4). Variation in seed glucosinolate concentrations of Indian mustard (Brassica juncea L.) Czern and Coss has also earlier been reported by many authors [1,20,21].

\section{Variation for total glucosinolate content in leaves}

In leaves of selected 97 lines, NIRS data showed a range of 0.82102.30 with mean $\pm \mathrm{CV}$ value of $44.18 \pm 0.64$. RL-1359 had a high glucosinolate content of $86.92 \mu \mathrm{mol} / \mathrm{g}$ DW leaf and NUDH-YJ-04 had a low glucosinolate content of $10.17 \mu \mathrm{mol} / \mathrm{g}$ DW leaf. The frequency distribution of glucosinolate content in these 97 lines showed a discrete distribution (Figure 3) with 29 lines in range of 0-25 $\mu \mathrm{mol} / \mathrm{g}$ DW leaf 


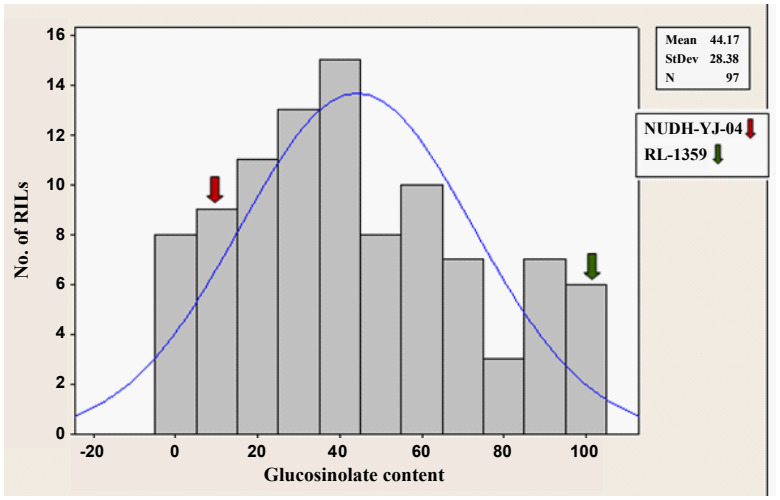

Figure 3: Frequency distribution of Glucosinolates in leaves via NIRS.

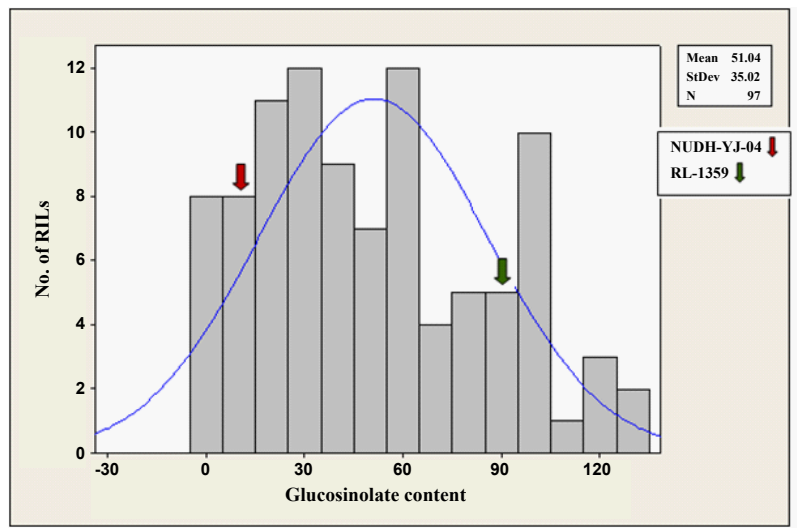

Figure 4: Frequency distribution of Glucosinolates in leaves via UPLC

\begin{tabular}{|l|l|l|l|l|l|}
\hline Tissue & & RL-1359 & NUDH-YJ-04 & Range & Mean \pm CV \\
\hline Seeds & 97 (NIRS) & 102.15 & 53.50 & $28.85-115.88$ & $69.39 \pm 0.26$ \\
\cline { 2 - 7 } & 97 (UPLC) & 97.51 & 52.54 & $15.73-127.61$ & $66.28 \pm 0.33$ \\
\hline \multirow{2}{*}{ Leaves } & 97 (UPLC) & 86.92 & 10.17 & $0.82-102.30$ & $44.18 \pm 0.64$ \\
\cline { 2 - 7 } & 97 (UPLC) & 102.25 & 14.19 & $4.33-129.93$ & $51.04 \pm 0.68$ \\
\hline
\end{tabular}

Table 4: Distribution of glucosinolate content in seeds ( $\mu$ mole/g seed) and leaves ( $\mu$ mole/g DW leaf) of $B$. juncea in selected 97 individuals.

tissue, 31 lines had 26-50 $\mu \mathrm{mol} / \mathrm{g}$ DW leaf range, 21 genotypes had 51$75 \mu \mathrm{mol} / \mathrm{g}$ DW leaf range, 15 lines had glucosinolates in range of 76$100 \mu \mathrm{mol} / \mathrm{g}$ DW leaf with only single individual in 101-125 $\mu \mathrm{mol} / \mathrm{g}$ DW leaf range. In UPLC analysis, these 97 lines showed variation of 4.33129.93 with RL-1359 having $102.25 \mu \mathrm{mol} / \mathrm{g}$ DW leaf and NUDH-YJ-04 was having $14.19 \mu \mathrm{mol} / \mathrm{g}$ DW leaf. The mean $\pm \mathrm{CV}$ value is $51.04 \pm 0.68$. The frequency distribution (Figure 4) showed a decreasing trend of glucosinolate content with range, as $0-25 \mu \mathrm{mol} / \mathrm{g}$ DW leaf glucosinolate content had 30 lines, 26-50 $\mu \mathrm{mol} / \mathrm{g}$ DW leaf range had 23 lines, 51$75 \mu \mathrm{mol} / \mathrm{g}$ DW leaf range had 19 lines, 76-100 $\mu \mathrm{mol} / \mathrm{g}$ DW leaf range had 15 lines, 101-125 $\mu \mathrm{mol} / \mathrm{g}$ DW leaf range had 9 lines and 126-150 $\mu \mathrm{mol} / \mathrm{g}$ DW leaf had a single genotype i.e. with increase in range of glucosinolate content, there was decrease in number of genotypes, thus suggesting lower glucosinoalte content predominated in leaves (Table $4)$.

Similar results have also been observed by many authors [22-26]. As there is very little variation in total GSL content via NIRS and UPLC, so it can be suggested that non-destructive and cost effective NIRS may be an alternative to laborious UPLC. Similar studies have also been done by Velasco and Becker [13].

\section{Profiling of glucosinolates}

The individual glucosinolates identified in extracts from the seed and leaf tissues of $B$. juncea lines studied are listed in the Table 5. In seeds and leaves, 5 and 3 different individual components were identified by comparison with the purified standard (Sinigrin) and on the basis of the use of internal standards (Glucotropaeolin). When glucosinolate profiles of leaf and seed tissue were compared, trend of concentration of individual components was found to be similar. In both leaves and seeds, the dominant glucosinolate was gluconapin (GNA), with sinigrin (SIN) as the next most abundant component. These results are in agreement with previous studies on this [2730,7,13]. Vaughan and Gordon [28] and Röbbelen and Thies [29] found a relationship between geographical origin and GSL profile of B. juncea; whereas the accessions from India and Pakistan contained mainly GNA, the accessions from other origins contained mainly SIN. Another main component in seeds was found to be glucoiberin (IBE) which was not reported in leaves and epiprogoitrin (EPI) showed its presence in leaf tissue only, not in seeds.

In seeds, GNA component ranged from 2.36-90.87 $\mu \mathrm{mol} / \mathrm{g}$ DW seed with mean $\pm \mathrm{CV}$ value of $48.01 \pm 0.00$. The parent, RL-1359 showed high GNA content $(75.12 \mu \mathrm{mol} / \mathrm{g}$ DW seed tissue $)$ and NUDHYJ-04 had showed low GNA content $(37.51 \mu \mathrm{mol} / \mathrm{g}$ DW seed tissue) as expected. The lowest concentration of SIN component was found to be $0.194 \mu \mathrm{mol} / \mathrm{g}$ DW seed, highest was the $35.16 \mu \mathrm{mol} / \mathrm{g}$ DW seed, and the mean \pm CV value of $11.78 \pm 0.00$ in the RIL. RL-1359 had 19.73 $\mu \mathrm{mol} / \mathrm{g}$ DW seed SIN and NUDH-YJ-04 had $11.09 \mu \mathrm{mol} / \mathrm{g}$ DW seed SIN. IBE showed lesser concentration. In this case, high glucosinolate parent i.e. RL-1359 had lesser concentration of IBE $(2.12 \mu \mathrm{mol} / \mathrm{g}$ DW seed tissue) whereas low glucosinolate parent i.e. NUDH-YJ-04 had higher concentration of IBE $(3.16 \mu \mathrm{mol} / \mathrm{g}$ DW seed $)$. Range observed was $0.117-10.93 \mu \mathrm{mol} / \mathrm{g}$ DW seed with mean $\pm \mathrm{CV}$ value of $2.08 \pm 0.00$. Traces of two individual components NAS and NEO have also showed their presence. NAS was observed in RL-1359 only $(0.547 \mu \mathrm{mol} / \mathrm{g}$ DW seed) and it ranged from 0.0-6.10 $\mu \mathrm{mol} / \mathrm{g}$ DW seed with mean $\pm \mathrm{CV}$ value of $0.706 \pm 0.00$. Again in case of NEO, low glucosinolate parent had high concentration $(0.728 \mu \mathrm{mol} / \mathrm{g}$ DW seed $)$ as compared to high glucosinolate parent $(0.0027 \mu \mathrm{mol} / \mathrm{g}$ DW seed $)$. NEO concentration ranged from $0.0027-0.99 \mu \mathrm{mol} / \mathrm{g}$ DW seed in selected 97 individuals with mean $\pm \mathrm{CV}$ value of $0.1446 \pm 0.00$. Bellostas et al. [5] also observed that GNA concentration was highest in seeds of red cabbage $(0.2$ $\mu \mathrm{mol} / \mathrm{g}$ DW seed in cauliflower to $7.3 \mu \mathrm{mol} / \mathrm{g}$ DW seed in red cabbage). Also, SIN has already been reported as the quantitatively dominating glucosinolate in edible cabbage and cauliflower heads [25,31-34] with values ranging from 6-125 $\mu \mathrm{mol} / \mathrm{g}$ DW seed [35], depending upon the cultivar and the tissue assessed. Palmer et al. [36] reported SIN as the major glucosinolate in B.carinata, B.nigra and B. juncea, whereas other glucosinolates such as GNA appeared in lower concentration. But in

\begin{tabular}{|l|l|l|l|l|l|}
\hline Tissue & & RL-1359 & NUDH-YJ-04 & Range & Mean \pm CV \\
\hline Seeds & IBE & 2.12 & 3.16 & $0.117-10.93$ & $2.08 \pm 0.00$ \\
\hline & SIN & 19.73 & 11.09 & $0.194-35.16$ & $11.78 \pm 0.00$ \\
\hline & GNA & 75.12 & 37.51 & $2.36-90.87$ & $48.01 \pm 0.00$ \\
\hline & NAS & 0.547 & - & $0.0-6.10$ & $0.706 \pm 0.00$ \\
\hline & NEO & 0.0027 & 0.728 & $0.0027-0.99$ & $0.1446 \pm 0.00$ \\
\hline Leaves & EPI & 10.61 & 2.04 & $0.65-16.37$ & $3.98 \pm 0.08$ \\
\hline & SIN & 18.60 & 1.09 & $0.089-64.85$ & $14.10 \pm 0.11$ \\
\hline & GNA & 73.04 & 11.06 & $0.653-70.12$ & $12.46 \pm 0.00$ \\
\hline
\end{tabular}

IBE- glucoiberin, SIN- sinigrin, GNA- gluconapin, NAS- gluconasturtiin, NEOgluconeobrassicin, EPIPRO- epiprogoitrin

Table 5: Distribution of individual glucosinolate components in seeds ( $\mu \mathrm{mole} / \mathrm{g}$ DW seed) and leaves ( $\mu$ mole/g DW leaf) of B. juncea in selected 97 individuals. 
Citation: Gupta S, Sangha MK, Kaur G, Atwal AK, Banga S, et al. (2012) Variability for Leaf and Seed Glucosinolate Contents and Profiles in a Germplasm Collection of the Brassica juncea. Biochem Anal Biochem 1:120. doi:10.4172/2161-1009.1000120

Page 4 of 5

our study, GNA was found to be maximum. Bellostas et al. [5] also reported that some $B$. juncea cultivars have SIN as the main component while GNA as the dominant compound in others. Variability among previous studies is not surprising and can be explained considering first of all the different $B$. juncea varieties used in those studies which also interplay with other factors, such as growing conditions and agronomic practices that can affect plant glucosinolate profiles [37].

In leaves also, GNA concentration showed a diverse range from 0.653-70.12 $\mu \mathrm{mol} / \mathrm{g}$ DW leaf with mean $\pm \mathrm{CV}$ value of $12.46 \pm 0.00$. RL-1359 had $73.04 \mu \mathrm{mol} / \mathrm{g}$ DW leaf GNA and NUDH-YJ-04 had concentration of $11.06 \mu \mathrm{mol} / \mathrm{g}$ DW leaf tissue. SIN concentration was very low in NUDH-YJ-04 (1.09 $\mu \mathrm{mol} / \mathrm{g}$ DW leaf tissue) as compared to high glucosinolate parent $(18.60 \mu \mathrm{mol} / \mathrm{g}$ DW leaf tissue). SIN component ranged from $0.089-64.85 \mu \mathrm{mol} / \mathrm{g}$ DW leaf with mean $\pm \mathrm{CV}$ value of $14.10 \pm 0.11$. In EPI, range observed was $0.65-16.37 \mu \mathrm{mol} / \mathrm{g}$ DW leaf and mean \pm CV value was $3.983 \pm 0.08$. The parents, RL-1359 showed $10.61 \mu \mathrm{mol} / \mathrm{g}$ DW leaf EPI and NUDH-YJ-04 showed 2.04 $\mu \mathrm{mol} / \mathrm{g}$ DW leaf EPI.

Remarkable variation in glucosinolate content and profiles from different tissues within one plant may reflect different control mechanism operating on the glucosinolate biosynthetic pathway in different tissues or it may simply result from alterations in substrate availability [31]. Since, glucosinolates are known to arise from amino acid precursors [38], a comparative study of glucosinolate and amino acid profiles in different tissues should prove informative. Dynamic changes of glucosinolate levels in any particular tissue also depend upon regulation of de novo biosynthesis, degradation and mobilization of glucosinolates [39], with the capacity for the de novo synthesis varying according to the type of tissue concerned. Moreover, the chemical structure and glucosinolate concentrations in plants vary considerably, depending on the stage of development, tissue type and environmental conditions $[37,40]$, suggesting a storage function for these compounds which are required at specific stages of development [41]. Wide variation in glucosinolate content among genotypes, also suggest differences in their health promoting properties and the opportunity for enhancement of their levels through genetic manipulation [33].

Reports available so far on the correlation between total seed GSL content and GSL content in other plant tissues appear to be contradictory. Some authors have reported high positive correlations $[42,43]$, but others did not find any in other materials [44,45,32] as in present study. Schilling and Friedt [43] suggested that weak correlations between seed and leaf GSL content might be caused by the dependence of leaf GSL content on environmental effects and growing stage. Other authors have indicated that intra-plant variations for GSLs are quantitative rather than qualitative $[46,29]$. Therefore, further evaluation of the glucosinolate content and composition in different plant tissues will have to elucidate how the variability for seed GSLs identified in the present study is reflected in other plant organs.

In conclusion, a typical GSL profile of selected accessions was detected after NIRS analyses and confirmed with HPLC. Additionally to the inherent interest of identifying variability for seed quality traits in Brassica, the results of the present study reveal that a fast NIRS screening including the evaluation of individual GSLs may also be useful to identify wrong taxonomic assignments in this genus. The application of an approach consisting of nondestructive NIRS screening followed by further HPLC analyses on preselected entries led to a fast and comprehensive evaluation of variability for total content and profile of seed GSLs in a germplasm collection of Brassica. This approach allowed us to complete the evaluation without destroying any seed in most of the accessions, which represents an important advance in the evaluation of GSLs in Brassica germplasm. ${ }^{\star}$ Details of individual components has been given in online resources (I-II)

\section{Acknowledgement}

We thank Department of Biotechnology, Government of India for funding this work. The present work was the part of the DBT project entitled "Tagging and marker assisted transfer of low glucosinolate trait in $B$. juncea".

\section{References}

1. Palmer MV, Sang JP, Oram RN, Tran DA, Salisbury PA (1988) Variation in seed glucosinolate concentrations of Indian mustard (Brassica juncea (L.) Czern and Coss). Aust J Exp Agri 28: 779-782.

2. Fereres E, Fernández-Martínez JM, Minguez Y, Domínguez J (1983) Productivity of Brassica juncea and B. carinata in relation to rapeseed. Proc. 6th Int. Rapeseed Congress, France.

3. Fahey J.W., Zalcmann A.T., Talalay P. (2001) The chemical diversity and distribution of glucosinolates and isothiocyanates among plants. Phytochem 56: 5-51.

4. Falk KL, Vogel K, Textor S, Bartram S, Hick A, et al. (2004) Glucosinolate biosynthesis: demonstration and characterization of the condensing enzyme of the chain elongation cycle in Eruca sativa. Glucosinolate biosynthesis: demonstration and characterization of the condensing enzyme of the chain elongation cycle in Eruca sativa. Phytochem 65:1073-1084.

5. Bellostas N, Sorensen JC., Sorensen H (2007) Profiling glucosinolates in vegetative and reproductive tissues of four Brassica species of the U-triangle for their biofumigation potential. J Sci Food Agric 87:1586-1594

6. Sorensen H (1990) Canola and rapeseed Glucosinolates: structure, properties, function, production, chemistry, nutrition and processing technology. Van Nostrand Reinhold, New York.

7. Love HK, Rakow G, Raney JP, Downey RK (1990) Development of low glucosinolate mustard. Can. J Plant Sci 70: 419-424.

8. Rosa EAS, Heaney RK, Fenwick GR, Portas CAM (1997) Glucosinolates in crop plants. Hort Rev 19: 99-115.

9. Kirkegaard JA, Sarwar M, Matthiessen JN (1998) Assessing the biofumigation potential of crucifers. Acta Hort 459.

10. Zhang Y, Talalay P, Cho CG, Posner GH (1992) A major inducer of anticarcinogenic protective enzymes from broccoli: isolation and elucidation of structure. Proc Natl Acad Sci U.S.A 89: 2399-2403.

11. Stoewsand GS (1995) Bioactive organosulfur phytochemicals in Brassica oleracea vegetables: a review. Food. Chem Toxic 33: 537-543.

12. Faulkner K, Mithen R, Williamson G (1998) Selective increase of the potentia anticarcinogen 4-methylsulphinylbutyl glucosinolate in broccoli. Carcinogenesis 19: $605-609$

13. Velasco L, Becker HC (2000) Variability for seed glucosinolates in a germplasm collection of the genus Brassica. Genet. Resour Crop Evol 47: 231-238.

14. Font R, Del Río M, Fernández-Martínez JM, De Haro A (1998) Determining quality components in Indian mustard by NIRS. Cruciferae Newsletter 20: 6768.

15. Font R, Del Río M, Fernández-Martínez JM, De Haro A (1998) Evaluation of Brassica juncea germplasm for quality components. Eucarpia. International Symposium on Breeding of Protein and Oil Crops. Pontevedra (Spain). Eur Assoc Res Plant Breed 119-120.

16. Velasco L., Möllers C. (1998) Nondestructive assessment of sinapic acid esters in Brassica species: II. Evaluation of germplasm and identification of phenotypes with reduced levels. Crop Sci 38: 1650-1654.

17. Gladis T. (1989) Die Gattung Brassica L. und die Reproduktion entomophiler Pflanzensippen in Genbanken. PhD Thesis, Zentralinstitut für Genetik und Kulturpflanzenforschung, Gatersleben, Germany.

18. Font R, Del Río M, Jose M, Fernandez MJM, De Haro A (2004) Use of Near Infrared Spectroscopy for screening the individual contents in Indian Mustard seed (Brassica juncea L. Czern and Coss). J Agric Food Chem 52: 3563-3569.

19. Sorensen H, Sorensen S, Bjergegaard C, Michaelsen S (1999) Chromatography 
Citation: Gupta S, Sangha MK, Kaur G, Atwal AK, Banga S, et al. (2012) Variability for Leaf and Seed Glucosinolate Contents and Profiles in a Germplasm Collection of the Brassica juncea. Biochem Anal Biochem 1:120. doi:10.4172/2161-1009.1000120

Page 5 of 5

and Capillary Electrophoresis in Food Analysis. The Royal Society of Chemistry, Cambridge, UK.

20. Kumar S, Yadav S, Chauhan J, Singh A, Kumar P (2004) Total glucosinolate estimation by complex formation between glucosinolates and tetrachloropalladate (II) using ELISA reader. J Food. Sci Technol 41: 63-65.

21. Bellostas N, Sorensen AD, Sorensen JC, Sorensen H (2007) Genetic variation and metabolism of glucosinolates. Adv Bot Res 45: 369-415.

22. Lewis J, Fenwick GR (1987) Glucosinolate content of Brassica vegetables: Analysis of twenty-four cultivars of calabrese (green sprouting broccoli, Brassica oleracea L. var. botrytis subvar. Cymosa Lam.). Food Chem 25: 259268.

23. Alemayehu N, Becker H (2005) Quantitative genetic analysis of total glucosinolate, oil and protein contents in Ethiopian mustard (Brassica carinata A. Braun). Eth. J Sci 28:141-150

24. Hill CB, Williams PH, Carlson DG, Tookey HL (1987) Variation in Glucosinolates in Oriental Brassica Vegetables. J Amer Soc Hort Sci 112: 309-313.

25. Bradshaw JE, Wilson RN (1993) Inbred line versus F1 hybrid breeding in Swedes (Brassica napus L. var. Napobrassica Peterm). Annals of Applied Biology113: 206-216.

26. Krzymanski J, Pietka T, Krotka K (1994) Combining ability and heterosis in diallel crosses of double low winter oilseed rape II: F1 and F2 generations. Oilseed Crops 15: 21-32.

27. Josefsson E (1972) Variation of pattern and content of glucosinolates in seed of some cultivated Cruciferae. Plant Breed. 68: 113-123.

28. Vaughan JG, Gordon El (1973) A taxonomic study of Brassica juncea using the techniques of electrophoresis, gas-liquid chromatography and serology. Ann Bot 37: 167-184.

29. Röbbelen G, Thies W (1980) Brassica Crops and Wild Allies: Variation in rapeseed glucosinolates and breeding for improved meal quality ( $2^{\text {nd }}$ edn.). Japan Scientific Societies Press, Tokyo.

30. Gland A, Röbbelen G, Thies W (1981) Variation of alkenyl glucosinolates in seeds of Brassica species. Plant Breed 87.

31. Sang JP, Mrncsrnron IR, Johnsrone PK, Tnuscorr RJ (1984) Glucosinolate profiles in the seed, root and leaf tissue of cabbage, mustard, rapeseed, radish and swede. Can J Plant Sci 64: 77-93.

32. Sarwar M, Kirkegaard JA, Wong PTW, Desmarchelier JM (1988) Biofumigation potential of Brassicas: III. In vitro toxicity of isothiocyanates to soilborne fungal pathogens. Plant and Soil 101: 108-118.

33. Kushad MM, Brown AF, Kurilich AC, Juvik JA, Klein BP, et al. (1999) Variation of glucosinolates in vegetable crops of Brassica oleracea. J Agric Food Chem 47:1541-1548

34. Charron CS, Saxton AM, Sams CE (2005) Relationship of climate and genotype to seasonal variation in the glucosinolate-myrosinase system I. Glucosinolate content in ten cultivars of Brassica oleracea grown in fall and spring seasons. J Sci Food Agric 85: 671-681.

35. Tookey HL, Daxenblicher ME, Van Etten CH, Kwolek WF, Williams PH (1980) Cabbage glucosinolates: correspondence of patterns in seeds and leafy heads. J Am Soc Hortic Sci 105.

36. Palmer MV, Yeung SP, Sang JP (1987) Glucosinolate content of seedlings, tissue cultures, and regenerant plants of Brassica juncea (Indian mustard). J Agric Food Chem 35: 262-269.

37. Barbieri G, Pernice R, Maggio A, Pascale S, Fogliano V (2008) Glucosinolates profile of Brassica rapa L. subsp. Sylvestris L. Janch. var. esculenta. Hort Food Chem 107:1687-1691.

38. Kutacek M, Prochazka Z, Veres K (1962) Biogenesis of glucobrassicin, the in vitro precursor of ascorbigen. Nature 194: 393-394.

39. Chen S, Andreasson E (2001) Update on glucosinolate metabolism and transport. Plant Physiol Biochem 39: 743-758.

40. Velasco P, Cartea ME, Gonzalez C, Vilar M, Ordas A (2007) Factors affecting the glucosinolate content of kale (Brassica oleracea acephala group). J Agric Food Chem 55: 955-962.

41. Clossais-Besnard N, Larher F (1991) Physiological role of glucosinolates in
Brassica napus: Concentration and distribution pattern of glucosinolates among plant organs during a complete life cycle. J Sci Food Agric 56: 25-38.

42. Jurges K (1982) Möglichkeiten einer Auslese auf Glucosinolat- Armut in der Grünmasse von Brassica napus und B. campestris. Plant Breed 89: 74-87.

43. Schilling W, Friedt W (1991) Breeding of 00-rapeseed (Brassica napus L.) with differential glucosinolate content in the leaves. Proc. 8th Int. Rapeseed Conf. Saskatoon, Canada.

44. Mithen R (1992) Leaf glucosinolate profiles and their relationship to pest and disease resistance in oilseed rape. Euphytica 63: 71- 83.

45. Giamoustaris A, Mithen R (1995) The effect of modifying the glucosinolate content of leaves of oilseed rape (Brassica napus ssp. oleifera) on its interaction with specialist and generalist pests. Ann Appl Biol 126: 347-363.

46. Kjaer A (1976) The Biology and Chemistry of the Cruciferae: Glucosinolates in the Cruciferae. Academic Press, London. 